DOI:

\title{
OPTIMALISASI PEMANFAATAN JAHE (Zingiber officinale) DAN ROSELLA (Hibiscus sabdarifa) SEBAGAI MINUMAN KESEHATAN DI MADRASAH MUALLIMIN MUHAMMADIYAH YOGYAKARTA
}

\author{
Ginanjar Zukhruf Saputri ${ }^{1}$, Haafizah Dania ${ }^{2}$, Widyasari Putranti ${ }^{3}$ \\ Universitas Ahmad Dahlan Yogyakarta ${ }^{1,2,3}$ \\ Email : zukhruf.alparslan@gmail.com ${ }^{1}$
}

\begin{abstract}
ABSTRAK
Sekolah berbasis asrama memiliki beberapa permasalahan terutama di bidang kesehatan. Hasil survey dan skrining kesehatan yang telah dilakukan menunjukkan tingginya prevalensi penyakit menular seperti flu, batuk pilek $(16,5 \%)$ dan penyakit kulit seperti jamur, gatal, scabies $(11,2 \%)$. Adanya pos kesehatan pesantren di lingkungan sekolah tersebut diharapkan dapat mengoptimalkan promosi kesehatan dalam upaya pencegahan penyakit. Hal tersebut didukung pula dengan optimalisasi pemanfaatan TOGA (tanaman obat keluarga) yang ada di setiap asrama sekolah. Lahan yang cukup luas dan tempat tinggal (asrama) siswa yang terpisah menjadi peluang dalam pengembangan penanaman TOGA, didukung dengan pemanfaatan TOGA dalam bentuk sediaan minuman kesehatan dirasa lebih menarik dan penting untuk diupayakan sebagai salah satu kegiatan edukasi dan promosi kesehatan di lingkungan sekolah berbasis asrama. Kegiatan pemberdayaan masyarakat ini bertujuan untuk melakukan pendampingan pemanfaatan TOGA dan pelatihan pemanfaatan tanaman jahe (Zingiber officinale) dan tanaman rosella (Hibiscus sabdarifa) sebagai minuman kesehatan (syrup). Kegiatan pengabdian masyarakat ini meliputi dua sesi, yaitu sosialisasi hasil skrining kesehatan siswa dan edukasi kesehatan diri "swamedikasi" yang diikuti oleh pengelola madrasah, staf poskestren (perawat dan dokter), serta ibu pamong asrama (ummahat). Adapun kegiatan kedua adalah pelatihan pemanfaatan TOGA jahe (Zingiber officinale) dan rosella (Hibiscus sabdarifa) sebagai minuman kesehatan yang diikuti oleh 44 siswa Madrasah Mu'allimin Muhammadiyah Yogyakarta. Pengetahuan siswa sebelum dan sesudah pelatihan menunjukkan peningkatan skor rerata dari 5,56 menjadi 9,18 dengan nilai signifikansi $\mathrm{P}=0,000(\mathrm{P}<0,05)$. Hal ini menunjukkan bahwa pelatihan ini efektif dan dapat meningkatkan pengetahuan siswa Madrasah Mu'allimin Muhammadiyah Yogyakarta. Melalui pelatihan ini diharapkan siswa mampu mengaplikasikan terutama saat progam Mubaligh Hijrah yang menjadi salah satu program rutin Madrasah dalam praktek di masyarakat sekitar. Kegiatan ini diharapkan pula dapat ditindak lanjuti oleh poskestren untuk bersinergi dengan ibu pamong ataupun kantin untuk dapat mengoptimalkan TOGA di lingkungan asrama dan memulai produksi sediaan syrup kesehatan jahe dan rosella.
\end{abstract}

Key word: TOGA, jahe (Zingiber officinale), rosella (Hibiscus sabdarifa), pengetahuan

\begin{abstract}
Boarding school has some problems, especially in the health sector. According to health survey and screening results shown the high prevalence of infectious diseases such as flu, cold cough (16.5\%) and skin diseases such as candidiasis, itching, scabies (11.2\%). The existence of boarding health department (Poskestren) in the school is expected to optimize health promotion in efforts to prevent disease. This is also supported by optimizing the use of TOGA (tanaman obat keluarga/ family medicinal plants) in each school dormitory. Extensive land and separate student residences provide opportunities for the development of TOGA planting, supported by the use of TOGA in the form of health drink preparations which are considered more interesting and important as an education and health promotion activity in a boarding school. This activity aims to provide assistance in the use of TOGA and training in the use of plants of ginger (Zingiber officinale) and rosella (Hibiscus sabdarifa) as a health drink (syrup). This activity includes two sessions, namely the socialization of the results of student health screening and "self-medication" self-health education followed by school managers, poskestren staff (nurses and doctors), as well as the boarding house mother (ummahat). The second activity was training on the utilization of TOGA ginger (Zingiber officinale) and rosella (Hibiscus sabdarifa) as health drinks which were attended by 44
\end{abstract}


students of Muhammadiyah Mu'allimin Yogyakarta. Students' knowledge before and after training showed an increase in the average score from 5.56 to 9.18 with a significance value of $\mathrm{P}=0.000(\mathrm{P}<0.05)$. This shows that this training is effective and can improve the knowledge of students of the Muhammadiyah Mu'allimin Yogyakarta School. Through this training, students are expected to be able to apply, especially during the Mubaligh Hijrah program, which is one of the routine Madrasah programs in practice in the surrounding community. This activity is also expected to be followed up by the Poskestren to work together to be able to optimize TOGA in the boarding school and start the production of ginger and rosella health syrup preparations.

Key word: TOGA, ginger (Zingiber officinale), rosella (Hibiscus sabdarifa), knowledge

\section{PENDAHULUAN}

Berdasarkan UU no. 36 tahun 2009 tentang Kesehatan, Kesehatan adalah keadaan sehat, baik secara fisik, mental, spritual maupun sosial yang memungkinkan setiap orang untuk hidup produktif secara sosial dan ekonomis (Anonim, 2009). Pembangunan dalam bidang kesehatan menjadi hal yang tidak terpisahkan dari pembangunan nasional. Salah satu upaya tersebut dapat dilakukan melalui penerapan dan pemanfaatan tanaman obat keluarga (TOGA) secara mandiri di masyarakat.

Pemanfaatan TOGA merupakan salah satu upaya mendukung Program Indonesia Sehat yang mengedepankan paradigma sehat, yakni menekankan pada tindakan promotif dan preventif sebagai upaya kesehatan dan pemberdayaan masyarakat. Melalui pemanfaatan TOGA diharapkan dapat meningkatkan kemampuan masyarakat dalam mencari solusi untuk masalah kesehatan secara mandiri sebagai upaya pertolongan pertama dalam keluarga, memelihara kesehatan, meningkatkan kesejahteraan serta sebagai sumber penyedia bahan baku obat tradisonal. Disamping itu keberadaan TOGA juga menjadi sarana pelestarian dan penghijauan sehingga menambah keindahan lingkungan.

Selain di masyarakat sekitar, pemanfaatan TOGA juga telah dilakukan di setiap sekolah. Hal ini bertujuan mengenalkan pada siswa terkait pemanfaatan obat herbal pada kasus penyakit ringan (swamedikasi). Berdasarkan hal tersebut, penanaman TOGA juga telah dikenalkan di Madrasah Muallimin Muhammadiyah, namun berdasarkan wawancara secara kualitatif dengan salah satu staf kesehatan UKS menerangkan bahwa pemanfaatan TOGA masih belum optimal.

Mengingat sekolah berbasis asrama memiliki banyak persoalan. Hal ini bukanlah hal yang tabu, dengan konsep asrama dimana warga asrama hidup bersama secara berkelompok dalam satu lingkungan yang homogen meningkatkan resiko terjadinya beberapa persoalan, salah satunya adalah permasalahan kesehatan ataupun penyakit. Hasil survey dan skrining 
kesehatan yang telah dilakukan menunjukkan tingginya prevalensi penyakit menular seperti flu, batuk pilek (16,5\%) dan penyakit kulit seperti jamur, gatal, scabies $(11,2 \%)$.

Adanya pos kesehatan pesantren di lingkungan sekolah tersebut diharapkan dapat mengoptimalkan promosi kesehatan dalam upaya pencegahan penyakit. Hal tersebut didukung pula dengan optimalisasi pemanfaatan TOGA (tanaman obat keluarga) yang ada di setiap asrama sekolah. Lahan yang cukup luas dan tempat tinggal (asrama) siswa yang terpisah menjadi peluang dalam pengembangan penanaman TOGA, didukung dengan pemanfaatan TOGA dalam bentuk sediaan minuman kesehatan dirasa lebih menarik dan penting untuk diupayakan sebagai salah satu kegiatan edukasi dan promosi kesehatan di lingkungan sekolah berbasis asrama. Kegiatan pemberdayaan masyarakat ini bertujuan untuk melakukan pendampingan pemanfaatan TOGA dan pelatihan pemanfaatan tanaman jahe (Zingiber officinale) dan tanaman rosella (Hibiscus sabdarifa) sebagai minuman kesehatan (syrup).

\section{METODE}

Kegiatan pemberdayaan masyarakat berupa pemanfaatan TOGA dan pelatihan pemanfaatan tanaman Jahe (Zingiber officinale) dan tanaman Rosella (Hibiscus sabdarifa) sebagai minuman kesehatan (syrup) menggunakan metode classical (ceramah) terkait edukasi pemanfaatan TOGA dan metode praktek dalam pelatihan pembuatan syrup. Kegiatan-kegiatan tersebut dilaksanakan pada 25 Februari 2018, 22 Maret 2018 dan 12 Mei 2018.

\section{HASIL, PEMBAHASAN DAN DAMPAK}

Kegiatan ini merupakan kegiatan berkelanjutan dari kegiatan skrining kesehatan yang sebelumnya telah dilaksanakan. Adapun hasil skrining kesehatan siswa disosialisasikan pada sesi pertama, dilanjutkan edukasi kesehatan diri dan swamedikasi. Sedangkan pelatihan pemanfaatan TOGA dalam kesehatan dilakukan untuk membekali siswa yang akan mengikuti program Mubaligh Hijrah (MH) selama Ramadhan di beberapa desa.

Hasil survey dan skrining kesehatan yang telah dilakukan menunjukkan tingginya prevalensi penyakit menular seperti flu, batuk pilek (16,5\%) dan penyakit kulit seperti jamur, gatal, dan scabies $(11,2 \%)$. Selain faktor lingkungan, faktor imunitas menjadi salah satu hal yang dapat berpengaruh pada penularan dan perkembangan penyakit setiap pasien. Beberapa penelitian telah menunjukkan bahwa konsumsi tanaman herbal seperti ekstrak meniran, jahe, kunyit, dapat meningkatkan system imun. Penelitian Dyah, M (2010) menunjukkan bahwa 
adanya peningkatan fagositosis ekstrak zat pedas rimpang jahe emprit dosis $25 \mathrm{mg} / \mathrm{Kg} \mathrm{BB}$ sebanding dengan imunostimulator sintetik (Levamisol hidroklorida 2,5 mg/Kg BB) dan imunostimulator alami (ekstrak Echinacea $10 \mathrm{~m} / \mathrm{Kg} \mathrm{BB}$ ).

Kegiatan ini bertujuan pula untuk mengoptimalkan green house yang ada di Madrasah Muallimin Muhammadiyah terutama tanaman obat keluarga (TOGA) dalam kesehatan. Kegiatan terdiri dari dua sesi yaitu materi pengenalan pemanfaatan TOGA jahe dan rosella dalam kesehatan dan sesi kedua berupa pelatihan pembuatan syrup jahe dan rosella. Sesi satu mengenalkan contoh-contoh TOGA beserta manfaatnya. Salah satunya adalah manfaat jahe (Zingiber officinale) dan Rosella (Hibiscus sabdarifa) yang dapat digunakan dalam kesehatan.

Jahe secara empiris banyak digunakan sebagai minuman kesehatan. Hal ini karena jahe mengandung shogaol dan gingerol yang memiliki aktivitas sebagai antiemetik. Penelitian menunjukkan bahwa 6-shogaol, 6-gingerol dan zingerone dapat menghambat respon dari reseptor 5-HT3 yang mana berperan dalam proses mual muntah (Late Inaki \& Jose Allue, 2016). Gingerol juga dapat berefek sebagai analgetika, sedatif, antipiretika dan motilitas gastrointestinal (Anonim, 2008). Penelitian oleh Ricardo Fabio C, et al (2009) menunjukkan efek imunomodulator dari jahe (Zingiber officinale), Salvia officinalis dan, Syzygium aromaticum, dalam bentuk minyak esensial yang diujikan pada sel tikus.

Rosella (Hibuscus sabdariffa) diketahui mengandung antoxian, dimana secara klinis telah terbukti memilki aktivitas antihipertensi. Penelitian oleh Arellano (2004) membandingkan kelompok ekstrak rosella dan captopril sebagai obat standar hipertensi, menunjukkan bahwa ekstrak rosella dengan dosis $10 \mathrm{~g} /$ hari sebelum makan dapat menurukan tekanan darah sistolik dari 139 menjadi $123 \mathrm{mmHg}$, dan menurunkan tekanan darah diastolik dari 90 menjadi 79,53 mmHg (Arellano, Herera A \& Tortoriello, 2004). Kandungan fenol dan flavonoid antosianin pada bunga rosella merah (Hibiscus sabdariffa L.) secara klinis memiliki aktivitas sebagai antioksidan dan dapat meningkatkan sistem imun. Hasil penelitian Azizah Syahrana, et al (2017) menunjukkan pemberian kapsul serbuk rosella (Hibiscus sabdariffa L.) dosis $500 \mathrm{mg} /$ hari selama 30 hari meningkatkan ekspresi IL-10, tetapi dalam batas nilai normal pada sukarelawan sehat. Interleukin adalah bagian dari sistem kekebalan tubuh yang disebut sitokin dimana dapat mengaktifkan sistem kekebalan tubuh. IL-10 merupakan sitokin anti-inflamasi, berfungsi menghambat produksi beberapa jenis sitokin lain (TNF- $\alpha$, IL-1, IFN$\gamma$, chemokine, dan IL-12) dan menghambat fungsi makrofag dalam membantu aktivasi sel T (Couper dkk., 2008; Niikura dkk., 2011). 
Potensi dari kedua TOGA ini dapat dimanfaatkan dalam bentuk syrup agar mudah dikonsumsi. Pemilihan sediaan syrup mempertimbangkan kemudahan dalam pembuatannya serta cara mengkonsumsinya.

Pada kegiatan ini diukur pula pengetahuan siswa terkait materi yang diberikan. Pengukuran pengetahuan siswa dilakukan dua kali yaitu sebelum dan sesudah pelatihan, menggunakan kuisioner yang berjumlah 10 item pertanyaan. Adapun hasil pengetahuan siswa sebelum dan sesudah mengikuti pelatihan tersaji pada Tabel 1.

Tabel. 1. Rerata pengetahuan siswa sebelum dan sesudah mengikuti pelatihan pemanfaatan TOGA (Jahe dan Rosella) dalam kesehatan

\begin{tabular}{ll}
\hline \multicolumn{1}{c}{ Keterangan } & Rerata (SD) \\
\hline $\begin{array}{l}\text { Pengetahuan sebelum penyuluhan } \\
\mathrm{n}=44\end{array}$ & $5,56(1,54)$ \\
$\begin{array}{l}\text { Pengetahuan setelah penyuluhan } \\
\mathrm{n}=44\end{array}$ & $9,18(0,84)$ \\
\hline
\end{tabular}

Rerata pengetahuan siswa selanjutnya dilakukan analisi statistic, menggunakan Uji Wilcoxon. Adapun median dan signifikasi pengetahuan siswa sebelum dan sesudah tersaji pada Tabel 2.

Tabel 2. Median dan signifikasi rerata pengetahuan sebelum dan sesudah pelatihan pemanfaatan TOGA dalam kesehatan

\begin{tabular}{ccc}
\hline Keterangan & $\begin{array}{l}\text { Median } \\
\text { (Minimum-Maksimum) }\end{array}$ & Nilai P \\
\hline Pengetahuan sebelum Penyuluhan & $5(3-10)$ & $0,000^{*}$ \\
Pengetahuan Sesudah Penyuluhan & $9(5-10)$ & \\
\hline
\end{tabular}

Keterangan: * (signifikan) $\mathrm{P}<0,05$

Pada Tabel 1 dan 2 menunjukkan perbandingan pengetahuan sebelum dan sesudah pelatihan. Terdapat 1 orang dengan hasil pengetahuan setelah penyuluhan lebih rendah daripada sebelum penyuluhan, 2 orang tetap dan 41 orang mengalami peningkatan yang baik dari sebelum penyuluhan. Pada uji statistik uji wilcoxon menunjukkan hasil $p=0,000$. Karena nilai $\mathrm{p}<0,05$ secara statisik terdapat perbedaan pengetahuan yang bermakna antara sebelum dan sesudah penyuluhan.

Hal ini menunjukkan bahwa secara umum siswa dapat mengetahui isi atau materi pelatihan. Selanjutnya, diharapkan siswa mampu memahami dan mempraktekkan minimal di lingkungan keluarga ataupun di masyarakat.

Melalui kegiatan pemberdayaan masyarakat ini diperoleh data prevalensi dan sebaran penyakit baik penyakit menular ataupun tidak menular. Kegiatan ini juga mampu Optimalisasi Pemanfaatan Jahe (Zingiber Officinale) Dan Rosella (Hibiscus Sabdarifa) (Ginanjar Zukhruf Saputri) | 245 
meningkatkan pengetahuan siswa dalam memanfaatkan TOGA dan pengolahan sederhana dalam bentuk sediaan syrup. Pelatihan ini diharapkan agar siswa mampu mengaplikasikan terutama saat progam Mubaligh Hijrah yang menjadi salah satu program rutin Madrasah dalam praktek di masyarakat sekitar. Kegiatan ini diharapkan pula dapat ditindak lanjuti oleh poskestren untuk bersinergi dengan ibu pamong ataupun kantin untuk dapat mengoptimalkan TOGA di lingkungan asrama dan memulai produksi sediaan syrup kesehatan jahe dan rosella.

\section{SIMPULAN}

Adapun kesimpulan dari kegiatan pengabdian masyarakat ini adalah optimalisasi TOGA dapat digunakan sebagai upaya prevalensi atau pencegahan penyakit menular yang menjadi permasalahan di lingkungan Madrasah. Melalui kegiatan pelatihan pemanfaatan jahe (Zingiber officinale) dan rosella (Hibiscus sabdariffa L.) sebagai minuman kesehatan dapat meningkatkan pemahaman siswa terhadap materi pelatihan dengan rerata skor 9,18 dengan nilai signifikansi 0,000

\section{DAFTAR PUSTAKA}

Anonim, 2008, http://goldbamboo.com/topic-t6386-al6Zingiber_officinale.html, diakses Agustus 2008

Anonim, 2009. UU Kesehatan no 36 tahun 2009

Arellano, Herera A \& Tortoriello. 2004. Effectiveness and tolerability of standardized extract from Hibiscus sabdariffa in patients with mild moderate hypertension: a controlled and randomized clinical trial. Phytomedicine, Science Direct. Vol 11, issue 5, pg 375-38. 2004

Azizah, Nur Syahrana, Akrom, Endang Darmawan, 2017. Efek Serbuk Bunga Rosella Merah (Hibiscus sabdariffa L.) terhadap Ekspresi IL-10 pada Sukarelawan Sehat. Jurnal Farmasi Dan Ilmu Kefarmasian Indonesia . Vol. 4 No. 1 Juli 2017

Couper, K. N., Blount, D. G. \& Riley, E. M. (2008). IL-10: The Master Regulator of Immunity to Infection, Ournal of Immunology. American Association of Immunologist; 180; 5771-5777.

Late Inaki \& Jose Allue, 2016. The Effectiveness of Ginger in the Prevention of Nausea and Vomiting during pregnancy and chemotherapy. Integr Med Insight, 2016.11: 11-17

Mellawati Dyah, Sudarsono dan Ag. Yuswanto. 2010. Pengaruh Pemberian Ekstrak Zat Pedas Rimpang Jahe Emprit Yang Disari Dengan Etanol 70\% Terhadap Fagositosis Makrofag Pada Mencit Jantan Yang Diinfeksi Dengan Listeria Monocytogenes. Majalah Obat Tradisional, 15(3), 112 - 120, 2010 
Niikura, M, Inone, S. I., \& Kobayashi, F. (2011). Role of Interleukin-10 in Malaria: Focusing on Coinfection With Lethal and Nonlethal Murine Malaria Parasites. Journal of Biomedicine and Biotechnology; 2011; 1-8.

Pusat promosi kesehatan. Kementrian kesehatan Republik Indonesia (http://promkes.depkes.go.id/pola-hidup-bersih-sehat)

Ricardo FC, Andriano LR, Gustavo S, Juliano SZ, 2009. Immunomodulatory activity of Zingiber officinale Roscoe, Salvia officinalis L. and Syzygium aromaticum L. essential oils: Evidence for humor- and cell-mediated response. Journal of Pharmacy and Pharmacology 61(7):961-7. 2009 
